\title{
Pubertal Changes in Biochemical Markers of Growth
}

\author{
Giovanni Federico Giampiero I. Baroncelli Teresa Vanacore Lisa Fiore \\ Giuseppe Saggese
}

Department of Reproductive Medicine and Pediatrics, Endocrine Unit, Division of Pediatrics, University of Pisa, Pisa, Italy

\section{Key Words}

Adolescents · Bone markers · Children · Growth hormone $\cdot$ Growth hormone deficiency $\cdot$ Leptin $\cdot$ Puberty

\begin{abstract}
Puberty is a crucial period of life during which dramatic hormonal changes induce notable modifications in linear growth, bone mass and body composition. These changes are associated with variations in some biochemical parameters such as markers of bone turnover and leptin, which may reflect changes in bone growth and fat mass, respectively. Children with growth hormone $(\mathrm{GH})$ deficiency have reduced concentrations of bone markers, which increase during $\mathrm{GH}$ administration, while the levels of leptin decrease. There have been few studies analysing the behaviour of bone markers during puberty in $\mathrm{GH}$-treated $\mathrm{GH}$-deficient patients and no studies analysing the behaviour of leptin. Results from a longitudinal study showed that there was no change in serum osteocalcin, carboxy-terminal propeptide of type I procollagen, and cross-linked carboxy-terminal telopeptide of type I collagen levels during puberty in $\mathrm{GH}$-treated $\mathrm{GH}$-deficient children. Some studies have shown that changes in markers of bone turnover and leptin after short-term $\mathrm{GH}$ treatment may predict the growth response (at 6-12 months) to $\mathrm{GH}$ administration in $\mathrm{GH}$ deficient children. At present, insufficient data are avail-
\end{abstract}

able for the clinical use of these parameters as markers of growth response during pubertal development and as predictors of long-term growth response to $\mathrm{GH}$ treatment in children with GH deficiency. Nevertheless, the use of more and possibly new markers might improve the accuracy of growth prediction models in the future.

Copyright $@ 2003$ S. Karger AG, Basel

\section{Introduction}

Puberty is characterized by profound somatic changes, such as a notable increase in linear growth, modifications in body composition and attainment of reproductive capacity, all of which are regulated by changes in the endocrine milieu. The increase in sex steroids, in particular oestradiol, enhances spontaneous growth hormone $(\mathrm{GH})$ secretion by more than two-fold in late puberty. Insulin-like growth factor I (IGF-I) and its major circulating binding protein, IGF-binding protein 3, also increase during puberty. The rises in the levels of sex steroids, $\mathrm{GH}$ and IGF-I are crucial for linear growth, acquisition of bone mass and muscle bulk [1]. In this review, the behaviour of biochemical markers that may reflect changes in bone turnover and fat tissues in both normal and GHdeficient patients will be discussed, in addition to their possible clinical value as markers of linear growth.

\begin{tabular}{ll}
\hline KARGER & ( ) 2003 S. Karger AG, Basel \\
0301-0163/03/0607-0046\$19.50/0 \\
$\begin{array}{l}\text { Fax +4161306 12 34 } \\
\begin{array}{l}\text { E-Mail karger@karger.ch } \\
\text { www.karger.com }\end{array}\end{array}$ & $\begin{array}{l}\text { Accessible online at: } \\
\text { www.karger.com/hre }\end{array}$
\end{tabular}

Dr. G. Federico

Clinica Pediatrica, Spedali Riuniti S. Chiara

Via Roma 67

IT-56125 Pisa (Italy)

Tel. +39 050993 109, Fax +39050888 622, E-Mail g.federico@med.unipi.it 
Table 1. Values of bone markers at diagnosis and during treatment in children with GHD

\begin{tabular}{|c|c|c|c|c|c|c|c|}
\hline \multirow[t]{2}{*}{ Author } & \multirow[t]{2}{*}{ Reference } & \multicolumn{5}{|c|}{ At diagnosis } & \multirow{2}{*}{$\frac{\text { During GH treatment }}{\text { Bone marker* }}$} \\
\hline & & $\mathrm{OC}$ & PICP & BAP & ICTP & PYR, DPYR & \\
\hline Carey et al. & 7 & & $\downarrow$ & & & & $\uparrow$ \\
\hline Delmas et al. & 8 & $\downarrow$ & & & & & $\uparrow$ \\
\hline Johansen et al. & 9 & $\downarrow$ & & & & & $\uparrow$ \\
\hline Sartorio et al. & 10 & $\downarrow$ & & & & & $\uparrow$ \\
\hline Trivedi et al. & 11 & & $\downarrow$ & & & & $\uparrow$ \\
\hline Zamboni et al. & 12 & $\downarrow$ & & & & & $\uparrow$ \\
\hline Kanzaki et al. & 13 & $\downarrow$ & & & & & $\uparrow$ \\
\hline Saggese et al. & 14 & $\downarrow$ & $\downarrow$ & & & & $\uparrow$ \\
\hline Kubo et al. & 15 & & & & $\downarrow$ & & $\uparrow$ \\
\hline Fujimoto et al. & 16 & & & & & $\downarrow$ & $\uparrow$ \\
\hline Rauch et al. & 17 & & & & & $\downarrow$ & $\uparrow$ \\
\hline Tobiume et al. & 18 & & & $\mathrm{~N}$ & & & $\uparrow$ \\
\hline Tapanainen et al. & 19 & & $\downarrow$ & & & & $\uparrow$ \\
\hline Vihervuori et al. & 20 & & $\downarrow$ & & $\mathrm{N}$ & & $\uparrow$ \\
\hline Boot et al. & 21 & $\mathrm{~N}$ & $\mathrm{~N}$ & & $\mathrm{~N}$ & & $\uparrow$ \\
\hline Baroncelli et al. & 22 & $\downarrow$ & $\downarrow$ & & $\downarrow$ & & $\uparrow$ \\
\hline
\end{tabular}

BAP = Bone alkaline phosphatase isoenzyme; DPYR = total deoxypyridinoline; ICTP = cross-linked carboxyterminal telopeptide of type I collagen; OC = osteocalcin; PICP = carboxy-terminal propeptide of type I procollagen; PYR $=$ total pyridinoline $. \downarrow=$ Decreased; $\uparrow=$ increased; $\mathrm{N}=$ normal.

* Refers to the same bone marker(s) assessed at diagnosis.

\section{Changes in Bone Markers in Healthy Individuals during Childhood and Adolescence}

Bone is a dynamic tissue that grows and remodels throughout life in response to physical load and the metabolic environment. In children and adolescents, biochemical markers of bone turnover reflect a combination of growth, modelling and remodelling of bone tissue.

Biochemical markers of bone formation, such as serum bone alkaline phosphatase isoenzyme, osteocalcin (OC), carboxy-terminal propeptide of type I procollagen (PICP), and markers for bone resorption, including cross-linked carboxy-terminal telopeptide of type I collagen (ICTP), show age-related changes with higher values during the first 2 years of life and puberty, and increases occurring earlier in girls than in boys [2-5]. These changes resemble the growth velocity curves. Urinary pyridinoline and deoxypyridinoline values peak in the second month of life and subsequently decrease until approximately 3 years of age. During puberty, pyridinoline and deoxypyridinoline increase in boys, while in girls, pubertal increase is observed in peptide-bound forms such as collagen type I cross-linked N-telopeptides [3, 5].

Pubertal Changes in Biochemical Markers of Growth
Van Coeverden et al. [6] showed in a recent study that serum levels of bone alkaline phosphatase isoenzyme, OC, amino-terminal propeptide of type I procollagen (PINP) and ICTP increased until maximum values were reached at pubertal stages G4 in boys and B3 in girls; sex steroids and IGF-I reached adult values at pubertal stage 4. These data suggest that measurement of bone marker concentrations may have a clinical value in assessing growth-related changes during childhood and adolescence.

\section{Changes in Bone Markers in GH-Deficient Children and Adolescents}

Some studies have shown that children with GH deficiency (GHD) have reduced bone marker values at diagnosis [7-22] (table 1). In addition, we found that the concentrations of PICP during $24 \mathrm{~h}$, but not those of OC, were growth velocity- and GH-dependent in GH-deficient children [23]. These data suggest that GHD affects bone turnover and this may represent a cause of reduced bone mineral density in children with GHD [24].

Horm Res 2003;60(suppl 1):46-51 
Table 2. Predictive value of growth response during GH treatment in children with GHD assessed by bone marker measurement

\begin{tabular}{|c|c|c|c|c|c|c|}
\hline Author & Reference & Bone marker type & $\begin{array}{l}\text { Time of measure- } \\
\text { ment of bone } \\
\text { marker (months) }\end{array}$ & $\begin{array}{l}\text { Time of assess- } \\
\text { ment of growth } \\
\text { velocity (months) }\end{array}$ & r & $\mathrm{p}$ \\
\hline Johansen et al. & 9 & $\mathrm{OC}$ & 3 & 12 & - & $<0.01$ \\
\hline Trivedi et al. & 11 & PICP & 3 & 12 & 0.87 & $<0.001$ \\
\hline Kanzaki et al. & 13 & $\mathrm{OC}$ & 1 & 12 & 0.66 & $<0.01$ \\
\hline Saggese et al. & 14 & PICP & 1 week & 6,12 & $0.61-0.72$ & $<0.001$ \\
\hline Kubo et al. & 15 & PICP & 1 & 12 & 0.68 & $<0.05$ \\
\hline Fujimoto et al. & 16 & PYR & 1 & 6 & 0.58 & $<0.05$ \\
\hline Rauch et al. & 17 & GAL-HYL & 3 & 12 & 0.76 & 0.002 \\
\hline Tobiume et al. & 18 & BAP & 3 & 12 & 0.53 & $<0.05$ \\
\hline Tapanainen et al. & 19 & PICP & 3 & 6 & 0.59 & $<0.05$ \\
\hline \multirow[t]{2}{*}{ Vihervuori et al. } & 20 & OC, ICTP & 1 week & 12 & $0.61-0.67$ & $<0.05$ \\
\hline & & PICP & 3 & 12 & 0.50 & $<0.05$ \\
\hline Spagnoli et al. & 26 & PYR, DPYR & 1 & 12 & 0.82 & $<0.05$ \\
\hline Schonau et al. & 27 & PICP, DPYR & 1 & 12 & 0.77 & $<0.001$ \\
\hline Baroncelli et al. & 22 & OC, PICP, ICTP & 6,12 & $\begin{array}{l}12 \text { up to } \\
\text { final height }\end{array}$ & $0.02-0.36$ & NS \\
\hline
\end{tabular}

$\mathrm{BAP}=$ Bone alkaline phosphatase isoenzyme; $\mathrm{DPYR}=$ total deoxypyridinoline $;$ GAL-HYL $=$ galactosyl-hydroxylysine; ICTP = cross-linked carboxy-terminal telopeptide of type I collagen; OC = osteocalcin; PICP = carboxyterminal propeptide of type I procollagen; PYR = total pyridinoline.

Furthermore, some studies have demonstrated that GH treatment increases the values of bone markers [722] (table 1), suggesting that GH stimulates bone turnover. We observed that during GH treatment, bone marker values peaked at 12 months, probably reflecting the number and activity of the recruited osteoblasts (OC and PICP), and an increased action of osteoclasts on bone matrix or change in the activation frequency of new remodelling units (ICTP) [22]. After the first year of treatment, the mean levels of OC and PICP progressively declined, while the mean levels of ICTP remained stable until final height was achieved [22]. Similar results were reported by Boot et al. [21] after a 2-year follow-up. We did not, however, observe any changes in the levels of serum OC, PICP and ICTP in these patients during puberty [22]. In children with GHD, the increased bone turnover may reflect stimulation of linear growth and recovery of bone mineral density [21, 24].

The dynamics of bone markers during long-term GH treatment may suggest the occurrence of a progressive prevalence of bone resorption over bone formation, but it must be noted that bone markers provide only a qualitative assessment of bone formation or resorption, and that their serum levels cannot be directly translated into rates of bone formation or resorption [25]. Comparing the degree of variation of markers of bone formation with that of markers of bone resorption may not be justified because they probably reflect different aspects of growth. Indeed, a small change in one marker may be more important than a large change in another marker.

\section{Bone Markers and Growth Response to GH Treatment in GH-Deficient Children}

Some studies in GH-deficient children have shown that an increase in biochemical markers of bone turnover during the first weeks or months of GH treatment predicted growth rate within 6 or 12 months of therapy [9, 11, 13-20, 22, 26, 27] (table 2). This suggests that their measurement may be a useful tool in assessing responsiveness to GH treatment. We failed, however, to demonstrate any relationship between short-term (after 6 and 12 months of GH therapy) changes in bone markers (OC, PICP and ICTP) and long-term growth rate or final height in children with GHD [22]. Nonetheless, other factors may influence linear growth independently of the effect of $\mathrm{GH}$ on bone turnover. It should be considered that the bone markers we examined are not specific markers of longitudinal growth, which is primarily a function of 
growth plate cartilage activity [4]. In GH-deficient children, therefore, growth response to GH treatment cannot be predicted solely by changes in the levels of bone markers during treatment. The predictive power of bone markers on long-term GH treatment may be improved by their inclusion into a more complex prediction model that takes into account clinical findings, other biochemical parameters and additional biochemical bone markers.

\section{Leptin: A Marker of Fat Mass}

Adipocytes express and secrete leptin, a protein encoded by the $o b$ gene, which is involved in the regulation of satiety and body fat [28]. In healthy children and adolescents, leptin is related to body mass index (BMI). In particular, a strong exponential relationship in girls, but a weak association in boys, has been reported [29]. By stratifying the analysis according to pubertal stages, the association between blood leptin and BMI was shown to be similar at pubertal stages 1 and 2 in boys and girls. As pubertal development proceeded, the levels of leptin at a given BMI decreased in boys and increased in girls [29]. Thus, it appears that after pubertal stage 2 , there is a sexual dimorphism in the levels of serum leptin and that this sex difference is especially evident in late puberty. The lower levels of leptin found in boys in late puberty may be explained, in part, by a suppressive effect of the increasing concentrations of circulating androgens, as demonstrated by studies on hypogonadal men receiving androgen replacement therapy [30, 31]. In addition, it was observed that oestradiol concentrations correlated positively with leptin levels in pubertal girls, while testosterone concentrations correlated negatively with blood leptin [32]. By associating leptin levels with percentage body fat, measured by electric impedance, Blum et al. [29] found a strong correlation in both boys and girls, suggesting that fat mass is the main regulator of leptin levels and that BMI correlates with leptin because it reflects fat mass in a certain way. These data suggest that the reference range of leptin should include BMI and pubertal stage.

\section{Changes in Leptin in GH-Deficient Children}

It has generally been observed that $\mathrm{GH}$ administration decreases serum levels of leptin in GH-deficient children $[33,34]$. In one study, Matsuoka et al. [34] showed that GH administration to children with GHD was associated with a reduction in leptin levels to approximately $79 \%$ of baseline values after 10 days of treatment. Absolute levels of leptin showed a high correlation with absolute total body fat at the start and end of the study; a moderate correlation was observed between the 1-year change in total body fat and leptin. When blood leptin was expressed per unit fat mass, however, there was no difference between mean values at the start and after 1 year of GH treatment, suggesting that GH does not have an independent effect on leptin other than via a reduction in fat mass [34]. Other investigators, however, reported that GH may have a direct effect on leptin production, metabolism or clearance because the levels of leptin declined before changes in body composition occurred [35].

$\mathrm{GH}$-induced changes in circulating leptin make this protein a possible metabolic marker of growth response to GH. Kriström et al. [33] studied the behaviour of serum leptin levels and height standard deviation score (SDS) in 150 short children with a broad range of GH secretory capacity, 86 of whom had GHD. All patients were treated with GH and were followed for at least 1 year. Changes in height SDS after 1 year of GH treatment correlated positively with levels of serum leptin at the start of GH therapy and negatively with serum leptin levels after 3 months of $\mathrm{GH}$ administration. By adding baseline concentrations of serum leptin to other pre-treatment variables, such as growth pattern before the age of 2 years, IGF-I SDS and $\mathrm{GH}$ peak in the arginine-insulin tolerance test, the power of the model to explain variations in growth response to GH improved from 46 to $58 \%$. Thus, both pre-treatment and short-term changes in the levels of serum leptin in response to GH administration may be useful markers for the prediction of first-year growth response.

\section{Leptin and Bone Markers}

Recently, it was discovered that leptin may regulate osteoblast activity both indirectly and directly. Intraventricular infusion of leptin for 20 days in $o b / o b$ mice and in wild-type mice caused a decrease in bone mass and volume through the hypothalamus [36], while intraperitoneal infusion over the same period increased femoral length in these mice [37]. It was hypothesized that the local environment may provide bone cells with signals favouring constant growth, whereas the central negative signal determines the density and length regulated by energy metabolism and leptin [38]. Functioning receptor isoforms for leptin were found in rat osteoblasts [39]. It was also reported that leptin may inhibit osteoclast generation in cultures of human peripheral blood mononuclear cells 
[40], while acting as a growth factor on the chondrocytes of skeletal growth centres in mice [41].

In healthy men, serum leptin levels correlated negatively with markers of bone formation and positively with markers of bone resorption, suggesting that leptin may stimulate bone resorption in adulthood [42]. In contrast, levels of leptin correlated negatively with markers of bone resorption in fetal blood, suggesting that leptin might promote bone formation during fetal life [43]. This contrasting behaviour may, however, reflect differences in age, metabolism and endocrine milieu.

\section{Conclusions}

In summary, GH status and GH treatment influence bone marker values. They may predict short-term growth response to $\mathrm{GH}$ treatment, but not long-term growth response or final height, when examined using univariate analysis. Moreover, GH treatment does not influence levels of bone markers during puberty. Serum levels of leptin may predict short-term growth response to GH treatment, but no data are available to consider leptin as a predictor of long-term growth response in GH-treated GH-deficient children.

\section{References}

1 Mauras N: Growth hormone and sex steroids. Interactions in puberty. Endocrinol Metab Clin North Am 2001;30:529-544.

2 Saggese G, Bertelloni S, Baroncelli GI, Di Nero G: Serum levels of carboxyterminal propeptide of type I procollagen in healthy children from 1st year of life to adulthood and in metabolic bone disease. Eur J Pediatr 1992;151:764768.

3 Calvo MS, Eyre DR, Gundberg CM: Molecular basis and clinical application of biological markers of bone turnover. Endocr Rev 1996; 17:333-368.

4 De Ridder CM, Delemarre-Van de Waal HA: Clinical utility of markers of bone turnover in children and adolescents. Curr Opin Pediatr 1998;10:441-448.

5 Szulc P, Seeman E, Delmas PD: Biochemical measurements of bone turnover in children and adolescents. Osteoporos Int 2000;11:281294.

6 Van Coeverden SCCM, Netelenbos JC, de Ridder CM, Roos JC, Popp-Snijders C, Delemarre-Van de Waal HA: Bone metabolism markers and bone mass in healthy pubertal boys and girls. Clin Endocrinol 2002;57:107116.

7 Carey DE, Goldberg B, Ratzan SK, Rubin KR, Rowe DW: Radioimmunoassay for type I procollagen in growth hormone-deficient children before and during treatment with growth hormone. Pediatr Res 1985;19:8-11.

8 Delmas PD, Chatelain P, Malaval L, Bonne G: Serum bone Gla-protein in growth hormone deficient children. J Bone Miner Res 1986;1: 333-338.

9 Johansen JS, Jensen SB, Riis BJ, Rasmussen L, Zachmann M, Christiansen C: Serum bone Gla-protein: a potential marker of growth hormone $(\mathrm{GH})$ deficiency and the response to $\mathrm{GH}$ therapy. J Clin Endocrinol Metab 1990;71: 122-126.

10 Sartorio A, Conti A, Guzzaloni G, Faglia G: Serum osteocalcin levels in patients with growth hormone $(\mathrm{GH})$ deficiency before and during GH treatment. Acta Paediatr Scand 1991;80:100-102.
11 Trivedi P, Risteli J, Risteli L, Hindmarsh PC, Brook CGD, Mowat A: Serum concentrations of the type I and III procollagen propeptides as biochemical markers of growth velocity in healthy infants and children and in children with growth disorders. Pediatr Res 1991;30: 276-280.

12 Zamboni G, Antoniazzi F, Radetti G, Musumeci C, Tatò L: Effect of two different regimens of recombinant human growth hormone therapy on the bone mineral density of patients with growth hormone deficiency. J Pediatr 1991;119:483-485.

13 Kanzaki S, Hosoda K, Moriwake T, Tanaka H, Kubo T, Inoue M, Higuchi J, Yamaji T, Seino $\mathrm{Y}$ : Serum propeptide and intact molecular osteocalcin in normal children and children with growth hormone $(\mathrm{GH})$ deficiency: a potential marker of bone growth and response to $\mathrm{GH}$ therapy. J Clin Endocrinol Metab 1992;75: 1104-1109.

14 Saggese G, Baroncelli GI, Bertelloni S, Cinquanta L, Di Nero G: Effects of long-term treatment with growth hormone on bone and mineral metabolism in children with growth hormone deficiency. J Pediatr 1993;122:3745.

15 Kubo T, Tanaka H, Inoue M, Kanzaki S, Seino Y: Serum levels of carboxyterminal propeptide of type I procollagen and pyridinoline crosslinked telopeptide of type I collagen in normal children and children with growth hormone (GH) deficiency during GH therapy. Bone 1995; 17:397-401.

16 Fujimoto S, Kubo T, Tanaka H, Miura M, Seino Y: Urinary pyridinoline and deoxypyridinoline in healthy children and in children with growth hormone deficiency. J Clin Endocrinol Metab 1995;80:1922-1928.

17 Rauch F, Schnabel D, Seibel MJ, Remer T, Stabrey A, Michalk D, Schonau E: Urinary excretion of galactosyl-hydroxylysine is a marker of growth in children. J Clin Endocrinol Metab 1995;80:1295-1300.
18 Tobiume H, Kanzaki S, Hida S, Ono T, Moriwake $\mathrm{T}$, Yamauchi S, Tanaka $\mathrm{H}$, Seino $\mathrm{Y}$ : Serum bone alkaline phosphatase isoenzyme levels in normal children and children with growth hormone $(\mathrm{GH})$ deficiency: a potential marker for bone formation and response to $\mathrm{GH}$ therapy. J Clin Endocrinol Metab 1997;82: 2056-2061.

19 Tapanainen P, Knip M, Risteli L, Kemppainen L, Kaar M-L, Risteli J: Collagen metabolites in the prediction of response to $\mathrm{GH}$ therapy in short children. Eur J Endocrinol 1997;137: 621-625.

20 Vihervuori E, Turpeinen M, Siimes MA, Koistinen H, Sorva R: Collagen formation and degradation increase during growth hormone therapy in children. Bone 1997;20:133-138.

21 Boot AM, Engels MAMJ, Boerma GJM, Krenning EP, De Muinck Keizer-Schrama SM: Changes in bone mineral density, body composition, and lipid metabolism during growth hormone $(\mathrm{GH})$ treatment in children with $\mathrm{GH}$ deficiency. J Clin Endocrinol Metab 1997;82: 2423-2428.

22 Baroncelli GI, Bertelloni S, Ceccarelli C, Cupelli D, Saggese G: Dynamics of bone turnover in children with growth hormone $(\mathrm{GH})$ deficiency treated with GH until final height. Eur J Endocrinol 2000;142:549-556.

23 Saggese G, Baroncelli GI, Bertelloni S, Cinquanta L, Di Nero G: Twenty-four-hour osteocalcin, carboxyterminal propeptide of type I procollagen, and aminoterminal propeptide of type III procollagen rhythms in normal and growth-retarded children. Pediatr Res 1994;35: 409-415.

24 Saggese G, Baroncelli GI, Bertelloni S, Barsanti S: The effect of long-term growth hormone (GH) treatment on bone mineral density in children with $\mathrm{GH}$ deficiency. Role of $\mathrm{GH}$ in the attainment of peak bone mass. J Clin Endocrinol Metab 1996;81:3077-3083. 
25 Weaver CM, Peacock M, Martin BR, McCabe GP, Zhao J, Smith DL, Wastney ME: Quantification of biochemical markers of bone turnover by kinetic measures of bone formation and resorption in young healthy females. J Bone Miner Res 1997;12:1714-1720.

26 Spagnoli A, Branca F, Spadoni GL, Cianfarani S, Pasquino AM, Argirò G, Vitale S, Robins SP, Boscherini B: Urinary pyridinium collagen crosslinks predict growth performance in children with idiopathic short stature and with growth hormone $(\mathrm{GH})$ deficiency treated with $\mathrm{GH}$ : skeletal metabolism during $\mathrm{GH}$ treatment. J Clin Endocrinol Metab 1996;81:3589_ 3593.

27 Schonau E, Westermann F, Rauch F, Stabrey A, Wassmer G, Keller E, Bramswig J, Blum WF: A new and accurate prediction model for growth response to growth hormone treatment in children with growth hormone deficiency. Eur J Endocrinol 2001;144:13-20.

28 Halaas JL, Gajiwala KS, Maffei M: Weightreducing effects of the plasma protein encoded by the obese gene. Science 1995;269:543-546.

29 Blum WF, Englaro P, Hanitsch S, Juul A, Hertel NT, Muller J, Skakkebaek NE, Heiman ML, Birkett M, Attanasio AM, Kiess W, Rascher W Plasma leptin levels in healthy children and adolescents: dependence on body mass index, body fat mass, gender, pubertal stage, and testosterone. J Clin Endocrinol Metab 1997;82 2904-2910.
30 Jockenhovel F, Blum WF, Vogel E: Testosterone substitution normalizes elevated leptin serum levels in hypogonadal men. J Clin Endocrinol Metab 1997;82:2510-2513.

31 Rolf C, Von Eckardstein S, Koken U, Nieschlag E: Testosterone substitution of hypogonadal men prevents the age-dependent increases in body mass index, body fat and leptin seen in healthy ageing men: results of a crosssectional study. Eur J Endocrinol 2002;146: 505-511.

32 Demerath EW, Towne B, Wisemandle W, Blangero J, Chumlea WC, Siervogel RM: Serum leptin concentration, body composition, and gonadal hormones during puberty. Int $\mathbf{J}$ Obes Relat Metab Disord 1999;23:678-685.

33 Kriström B, Carlsson B, Rosberg S, Carlsson LM, Albertsson-Wikland K: Short-term changes in serum leptin levels provide a strong metabolic marker for the growth response to growth hormone treatment in children. Swedish study group for growth hormone treatment. J Clin Endocrinol Metab 1998;83:2735-2741.

34 Matsuoka H, Fors H, Bosaeus I, Rosberg S, Albertsson-Wikland K, Bjarnason R: Changes in body composition and leptin levels during growth hormone $(\mathrm{GH})$ treatment in short children with various $\mathrm{GH}$ secretory capacities. Eur J Endocrinol 1999; 140:35-42.

35 Elimam A, Lindgren AC, Norgren S, Kamel A, Skwirut C, Bang P, Marcus C: Growth hormone treatment downregulates serum leptin levels in children independent of changes in body mass index. Horm Res 1999;52:66-72.

36 Ducy P, Amling M, Takeda S, Priernel M, Schilling AF, Bell FT, Shen J, Vinson C, Rueger JM, Karsenty G: Leptin inhibits bone formation through a hypothalamic relay: a central control of bone mass. Cell 2000;100:197-207.
37 Steppan MC, Crawford DT, Chidsey-Frink $\mathrm{KL}, \mathrm{Ke} \mathrm{H}$, Swick AG: Leptin is a potent stimulator of bone growth in $o b / o b$ mice. Regul Pept 2000;92:73-78.

38 Reseland JE, Gordeladze JO: Role of leptin in bone growth: central player or peripheral supporter? FEBS Lett 2002;578:40-42.

39 Lee YJ, Park JH, Ju SK, You KH, Ko JS, Kim HM: Leptin receptor isoform expression in rat osteoblasts and their functional analysis. FEBS Lett 2002;528:43-47.

40 Holloway WR, Collier FM, Aitken CJ, Myers DE, Hodge JM, Malakellis M, Gough TJ, Collier GR, Nicholson GC: Leptin inhibits osteoclast generation. J Bone Miner Res 2002;17: 200-209.

41 Maor G, Rochwerger M, Segev Y, Phillip M: Leptin acts as a growth factor on the chondrocytes of skeletal growth centers. J Bone Miner Res 2002; 17:1034-1043.

42 Sato M, Takeda N, Sarui H, Takami R, Takami K, Hayashi M, Sasaki A, Kawachi S, Yoshino K, Yasuda K: Association between serum leptin concentrations and bone mineral density, and biochemical markers of bone turnover in adult men. J Clin Endocrinol Metab 2001;86: 5273-5276.

43 Ogueh O, Sooranna S, Nicolaides KH, Johnson MR: The relationship between leptin concentration and bone metabolism in the human fetus. J Clin Endocrinol Metab 2000;85:1997_ 1999. 